\title{
Redaksionele voorwoord
}

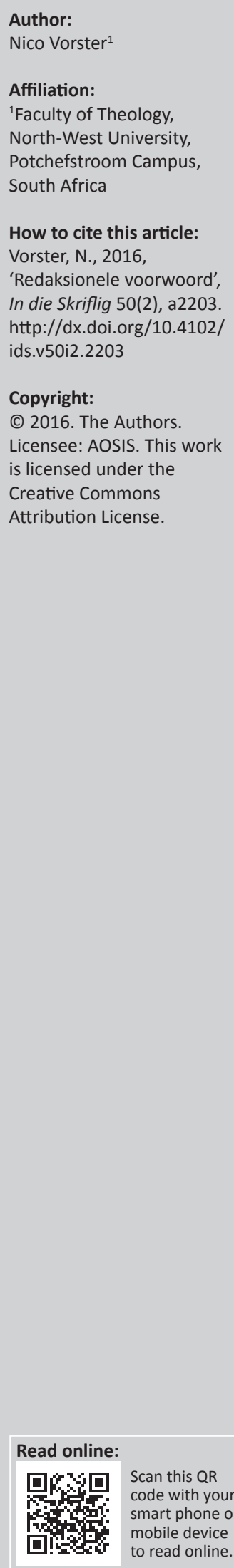

Dit is ' $n$ besondere voorreg om as gasredakteur van hierdie Festschrift vir Professor Fika Janse van Rensburg op te tree. Die bedoeling is om op 'n akademiese wyse erkenning aan die bydrae te gee wat Janse van Rensburg tot Teologie en die breëre Universiteitswese gelewer het. Janse van Rensburg se akademiese loopbaan begin in 1973 met sy aanstelling as tydelike dosent in Grieks aan die destydse PU vir CHO. In 1975 kry hy 'n voltydse aanstelling as Junior Lektor in Grieks en in 1978 word hy as Lektor aangestel. Na 'n bedieningsloopbaan van drie jaar word hy in 1983 as Hoof van die Departement Grieks aan die PU vir CHO aangestel. In dieselfde jaar word hy ook deur die GKSA as Professor in Nuwe Testament beroep en hy beklee die pos tot 2014.

Fika Janse van Rensburg het 'n besondere bydrae tot Universiteitsbestuur gelewer. Hy was onder meer Hoof van BA-, MA- en PhD-Programme aan die Fakulteit Teologie (1995-1997), Direkteur Bybelwetenskappe en Antieke Tale aan die NWU (1998-2009), Voorsitter van die Forum for University Theology Education in South Africa (2009-2014), Dekaan van die NWU se Fakulteit Teologie (2010-2014), Waarnemende Viserektor: Navorsing en Beplanning aan die NWU-Potchefstroomkampus (2015) en Waarnemende Rektor van die NWU Potchefstroomkampus (2016).

Op navorsingsgebied het Janse van Rensburg eweneens ' $n$ belangrike bydrae gelewer. Hy publiseer 63 wetenskaplike artikels en 40 hoofstukke in boeke, is alleenouteur van 4 boeke, en gesamentlike outeur en redakteur van 23 boeke. Janse van Rensburg lewer 17 Doktorale en 21 Meestersgraadstudente af. As erkenning vir sy bydrae tot teologiese navorsing op die gebied van die Nuwe Testament word verskeie pryse aan Janse van Rensburg toegeken. Hy ontvang agtereenvolgens in 1999 die ds Pieter van Drimelen-medalje van die Suid-Afrikaanse Akademie vir Wetenskap en Kuns vir sy bydrae tot Bybelvertaling en teologiese publikasies; in 2000 die Andrew Murray-prys vir sy werk as redakteur en mede-outeur van die Die Bybellennium; in 2000 die CBSA-medalje vir Die Bybellennium; en in 2004 die Andrew Murray-prys vir sy werk as redakteur en mede-outeur van Die Bybel A-Z.

Benewens sy publikasies dien Janse van Rensburg ook as Voorsitter van die Nuwe-Testamentiese Werksgemeenskap van Suid-Afrika (1995-2000), as Redakteur van die tydskrif, In die Skriflig (2000-2003), lid van die Redaksieraad van Neotestamentica (1990-2000), lid van die adviesraad van Theologia Reformata (2011-), en op die Redaksieraad van Acta Patristica et Byzantina (2009-). Vanaf 1997-2005 dien hy as alleen-verteenwoordiger van die Suid-Afrikaanse Universiteite op die National Standards Body for Human and Social Sciences (NSB07) van SAKO.

Verskeie bydraes in hierdie bundel val binne die navorsingsveld waar Janse van Rensburg sy belangrikste navorsingsbydrae gelewer het, naamlik die briewe van 1 en 2 Petrus. Benno Zuiddam ondersoek die outeur van 2 Petrus se ervaring van goddelike Openbaring en vergelyk dit met die Nederlandse Geloofsbelydenis se omskrywing van die goddelike outeurskap van die Bybel. Alistair Wilson poog om duidelikheid oor die betekenis van die begrip $\dot{\lambda} \lambda \pi$ í in die briewe van Kollosense en 1 Petrus te verkry. Hy bespreek spesifiek die ooreenkomste en verskille tussen die twee briewe se konsepte van hoop en die implikasies daarvan vir Nuwe-Testamentiese Teologie. Sebastian Fuhrmann fokus op die moontlike relasie tussen Hebreërs 2:14 se omskrywing van Christus se sterwe as 'n oorwinning oor die duiwel en die metafoor van die duiwel as 'n brullende leeu in 1 Petrus 5:8. Hy kom tot die slotsom dat albei tekste moontlik die Romeinse juridiese konsep van crimen calumniae as agtergrond het. Paul Decock hanteer die konsep van geestelike volwassenheid in 1 Petrus - spesifiek die proses van geestelike groei soos beskryf in 1 Petrus.

'n Tweede stel bydraes handel oor Pauliniese literatuur. Francois Tolmie ondersoek die wyse waarop vierde- en vyfde-eeuse eksegete Paulus se gesagsaansprake in die brief aan Filemon ontvang het. Hy identifiseer twee tendense by die betrokke eksegete. Eerstens aanvaar al die eksegete dat Paulus inderdaad gesag dra oor Filemon en tweedens beskou almal die wyse waarop Paulus sy gesag uitoefen as prysenswaardig en navolgenswaardig. Bruce Button gebruik konsepte vanuit French en 
Raven se mag en interaksie sosiaal-wetenskaplike model om Paulus se metode van beïnvloeding in die brief aan 1 Tessalonisense te ondersoek. Jeremy Punt stel ondersoek in na die wyse waarop Paulus sy eie maskuliniteit in 1 Korintiërs 11-13 aanbied. Hy meen dat hierdie invalshoek moontlik 'n alternatiewe blik op die Pauliniese briewe se verstaan van liggaamlikheid kan bied. Hermie van Zyl evalueer die bestaande eksegetiese en hermeneutiese argumente in die debat oor selfdegeslagverhoudings, spesifiek met betrekking tot Romeine 1:26-27. Hy meen dat 'n onderskeid in die debat getref moet word tussen eksegetiese en hermeneutiese insigte. Volgens Van Zyl gebruik pro-gay teoloë hermeneutiese insigte op 'n ongeldige wyse om die uitsprake van Romeine 1:26-27 oor homoseksuele gedrag te relativeer. Pieter de Villiers bespreek die konsep van goddelike liefde in die brief aan die Romeine. Hy argumenteer dat hierdie verwaarloosde tema in die Romeine brief van deurslaggewende belang vir die interpretasie van hierdie brief is.

Twee bydraes handel oor Johannese literatuur. Jan van der Watt vra of die veelbesproke inleiding tot die Johannesevangelie - Johannes 1:1 - nie moontlik 'n raaisel kan wees nie? Om 'n antwoord hierop te kry, ondersoek hy die ingewikkelde grammatika van hierdie vers. Jan du Rand bespreek die boodskap van 1 Johannes na aanleiding van Judith Lieu se onlangse retoriese analise van 1 Johannes. Ten einde 'n gebalanseerde blik op die boodskap en die identiteit van die eerste lesers van 1 Johannes te verkry, stel Du Rand voor dat 'n multi-dimensionele eksegetiese benadering tot 1 Johannes gevolg word.

Francois Viljoen en Andries van Aarde se bydraes fokus op die Matteusevangelie. Volgens Viljoen word die Matteusevangelie deur 'n onderliggende konflik tussen Jesus en die Fariseërs gekenmerk oor die gesagvolle interpretasie van die Tora. Die outeur van die evangelie beklemtoon dat Jesus, en nie die Fariseërs nie, die eintlike gesagvolle interpreteerder van die Tora is. Van Aarde se bydrae verduidelik die literêrteoretiese konsep van fiktiewe ensiklopedie en pas hierdie intertekstuele benadering op Matteaanse studie toe.
Twee bydraes in die bundel bied historiese navorsing. John Fitzgerald fokus op geskrifte van die tweede-eeuse filosoof en medikus Galen, en die belang daarvan vir NuweTestamentiese navorsing. Galen se benadering tot 'rou' vanuit 'n filosofiese en mediese perspektief gee volgens Fitzgerald belangrike konteks aan Nuwe-Testamentiese uitsprake oor lypē. Marius Nel en Fika Janse van Rensburg bied ' $n$ historiese perspektief op die lang en moeisame pad van teologiese opleiding vir voornemende pastore van die Apostoliese Geloofsending in Suid-Afrika.

Die laaste drie bydraes het 'n meer omvattende teologiese aanpak. Hennie Goede bespreek die verhouding tussen ouer en jonger geslagte in die Nuwe Testament. Hy bestudeer verskeie tekste wat oor die verhouding tussen ouer en jonger geslagte handel en kom tot die konklusie dat 'n gesonde verhouding tussen die betrokke geslagte volgens die Nuwe Testament uit wederkerige respek, liefde, nederigheid en ' $n$ gewilligheid om mekaar te dien, bestaan. Hans van Deventer bied 'n kritiese perspektief op die gebruik van die term Skrifkritiek binne die Gereformeerde wêreld. Hy bevraagteken die wetenskaplike akkuraatheid van die term, en stel voor dat Gereformeerde teoloë oor die gebruik daarvan herbesin. Koos Vorster sluit die bundel af met ' $n$ teologies-etiese perspektief op die tradisioneel Rooms-Katolieke konsep van die 'gemeenskaplike goeie'. Hy bespreek hoe daar vanuit ' $n$ reformaties-natuurregtelike perspektief nuwe inhoud aan hierdie term gegee kan word en hoe die konsep deur die kerk gebruik kan word om saam met die burgerlike gemeenskap sosiaal-verantwoordelike aksie in die samelewing te onderneem.

Die entoesiasme waarmee die onderskeie skrywers hierdie projek onderneem het, spreek boekdele van hulle respek vir Fika Janse van Rensburg. Met hierdie bundel gee die outeurs erkenning aan Janse van Rensburg as vriend en kollega asook vir sy bydrae tot die gereformeerde teologie, die NuweTestamentiese teologie, die tersiêre teologiese onderrig, die NWU en die Suid-Afrikaanse Universiteitswese. Mag sy nalatenskap nog vir lank voortleef! 